\section{Kastamonu Eğitim Dergisi Kastamonu Education Journal}

Temmuz 2019 Cilt:27 Sayı:4

kefdergi.kastamonu.edu.tr
Başvuru Tarihi/Received: 31.07.2018

Kabul Tarihi/Accepted: 20.09.2018

DOI: $10.24106 /$ kefdergi.3256

\title{
Öğretmen Adaylarının Spiritüel İyi Oluş İle Yaşamda Anlam Değişkenlerinin Psikolojik Dayanıkılığı Yordaması: Bir Yapısal Eşitlik Modeli (YEM) Denemesi
}

\author{
Predictive Role of Spiritual Well Being and Meaning in Life on \\ Psychological Hardiness Levels of Teacher Candidates': A Testing \\ Structural Equation Modelling (SEM)
}

\author{
Halil EKŞi' ${ }^{1}$, Cem BOYALI², Durmuş ÜMMET²
}

\section{Öz}

Bu çalışmanın amacı, öğretmen adaylarının spiritüel iyi oluş ve yaşamda anlam düzeylerinin psikolojik dayanıklılığı yordamadaki rolünü incelemektir. Çalışmada ilişkisel araştrrma modeli kullanılmıştır. Araştırmanın örneklemini Marmara Üniversitesi Atatürk Eğitim Fakültesi Pedagojik Formasyon biriminde öğrenim görmekte olan 338 öğrenci (276 kadın ve 62 erkek) oluşturmaktadır. Araştırmada veri toplama aracı olarak Kişisel Bilgi Formu, Spiritüel İyi Oluş Ölçeği, Psikolojik Dayanıklılık Ölçeği ve Yaşamda Anlam Ölçeği kullanılmıştır. Araştırmadan elde edilen veriler, SPSS 21.0 ve AMOS 20.0 programları kullanılarak analiz edilmiştir. Araştırmanın verilerinin analizinde, spiritüel iyi oluş ve yaşamda anlamın psikolojik dayanıklılık üzerindeki etkisi yapısal eşitlik modeli (YEM) yoluyla incelenmiştir. Yapısal eşitlik modeli sonucuna göre, psikolojik dayanıklılığın spiritüel iyi oluş ve yaşamda anlam tarafindan anlamlı bir şekilde açıklandığı tespit edilmiş ve bu değişkenler arasındaki ilişkiler örüntüsünü ortaya koyan modelin uyum indeksi değerlerinin iyi uyum verdiği görülmüştür.

Anahtar Kelimeler: psikolojik dayanıklılık, spiritüel iyi oluş, yaşamda anlam, öğretmen adayı, yapısal eşitlik modeli

\section{Abstract}

The purpose of this study is to investigate the prediction role of teacher candidates' spiritual well-being and meaning in life levels on psychological hardiness. Correlation research design was used in the study. The sample of the research is composed of 338 students (276 female and 62 male) who are studying at Marmara University Atatürk Education Faculty Pedagogical Formation unit. Personal Information Form, Spiritual Well-Being Scale, Psychological Hardiness Scale and Meaning in Life Scale were used as data collection tools in the research. The data of the study has been analyzed using SPSS 21.0 VE AMOS 20.0 programs. The effect of spiritual well-being and meaning in life on psychological hardiness were investigated via structural equation modelling (SEM) in the analysis of the research data. According to the results of the structural equation model, it has been found that psychological hardiness is significantly explained by spiritual well-being and meaning in life; and the model fit indices obtained fit well.

Keywords: psychological hardiness, spiritual well-being, meaning in life, teacher candidates, structural equation modeling

1. Marmara Üniversitesi, Eğitim Bilimleri Enstitüsü Yüksek Lisans Öğrencisi, İstanbul, Türkiye, https://orcid.org/0000-0002-7868-3011

2. Marmara Üniversitesi, Atatürk Eğitim Fakültesi, İstanbul, Türkiye; https://orcid.org/0000-0001-7520-4559

3. Marmara Üniversitesi, Atatürk Eğitim Fakültesi, İstanbul, Türkiye; https://orcid.org/0000-0002-8318-9026

Atıf / Citation: Ekşi, H., Boyalı, C., \& Ümmet, D. (2019). Öğretmen adaylarının spiritüel iyi oluş ile yaşamda anlam değişkenlerinin psikolojik dayanıklılığı yordaması: bir yapısal eşitlik modeli (yem) denemesi. Kastamonu Education Journal, 27(4), 1695-1704. doi:10.24106/kefdergi.3256 


\section{Extended Abstract}

Introduction: One of the greatest problems of humanity in the twenty-first century can be expressed as the "existential vacuum" or "the meaninglessness" in which humans have lived when they were not interested in a routine work or themselves (Corey, 2008). Today, there are economic, sociological and psychological factors that affect people and cause individuals to live in situations characterized as existential vacuum or meaninglessness. With many vital problems that people are trying to overcome, their quality of life also falls. Because of this intense chaos, individuals are unable to think of existential issues, to seek the meaning in life and to find out their purpose. People have different reference points in their effort of finding meaning in life, understanding themselves and the world. According to Steger, Kashdan, Sullivan and Lorentz (2008), the search for meaning can stem from different basic motivations in different people. Spirituality is a way that individuals often use to find the meaning of life. Spiritual well-being is an important indicator of an individual's perceived quality of life. The results of the research conducted by Shahidi and Hamdie (2002) show that people with a high level of spiritual well-being have a healthier lifestyle, are happier and more satisfied with their lives than other people (As cited in Mahdian \& Ghaffari, 2016).

Purpose: The purpose of this study is to investigate the predictive role of teacher candidates' spiritual well-being and meaning in life levels on psychological hardiness via Structural Equation Modelling (SEM). The problem of researching in this area can be determined as the question, "Does the level of meaning in life and spiritual well-being significantly predict the psychological hardiness levels of teacher candidates?".

Method: In this study, the predictive correlational research design was used for the correlational model types, because spiritual well-being and the effect of the level of meaning in life on psychological hardiness were examined. In the study, multi-stage cluster sampling method was applied as the sampling type. 344 teacher candidates constitute the sample of the researcher. Meaning in Life Questionnaire, Spiritual Well Being Scale and Psychological Hardiness Scale were used as data collection tools in the study. Personal information belonging to the participants is collected by the Personal Information Form created by the researcher. In the analysis of the obtained data, SPSS 21.0 statistical package program and AMOS 20.0 program were used.

Results and Suggestions: According to the findings of the research, there are significant positive correlations between spiritual well-being, meaning in life and psychological hardiness. In other words, the level of psychological hardiness increases as the level of spiritual well-being and the level of meaning in life increases in prospective the teachers. According to the research findings, it is seen that in the model of structural equality that is established, meaning in life and spiritual well-being are important predictive influences on the psychological hardiness of individuals.

The findings are consistent with both the field literature and other studies in limited numbers. The concept of spiritual well-being has become a concept that is handled in the context of mental health. It is stated that the spiritual well-being of the individual will contribute to the psychological health of the individual. From this point of view, "having positive qualities, avoiding negative qualities" has been regarded as a sign of well-being as well as health (Ventis, 1995), Spiritual orientation leads to meaningfulness, hope and transcendence (Çelimli and Güldal, 2016). In this context, it seems that spiritual well-being can be a variable that affects the level of meaning in life as well as the psychological well-being, which is defined as one of the greatest need of our times (Sayar, 2014). Psychological hardiness is seen as one of the dynamics that keeps individuals alive from the challenges of life. Kobasa (1979) sees psychological hardiness as a personal trait that acts as a source of resistance and protective shield against stressful life events. In this sense, it is seen that the characteristics of the psychologically meaningful and enduring individuals defined by Kobasa (1979) and the existentialist approach overlap with the views on meaning and spiritual well-being in life. All these discourses and other research findings support the findings of the model tested in this study. As a result, it is seen that both the spiritual well-being and the meaningfulness in life are significant predictors of the psychological hardiness of the prospective teachers who have the potential to be exposed to many stressful life events when they start their profession.

When the literature is examined, there is not a survey that contains three variables like in this research. Looking at the gap in the research, there is a need for work to be done upon these two variables. When psychological hardiness is thought to be an important function in the mental health of the individual, examination and determination of variables related to psychological hardiness are important for the development of preventive mental health services. It is also believed that the provision of education and training environment that can help teacher candidates in university education to be good in spiritual sense and add meaning to their lives and to organize psycho-education studies related to these subjects to increase the psychological hardiness of these individuals. 


\section{Giriş}

Yirmi birinci yüzyılda insanoğlunun en büyük problemlerinden biri, rutin olarak bir işle veya kendisiyle ilgilenmediği zaman yaşamış olduğu "varoluşsal boşluk" veya "anlamsızlık" durumu olarak ifade edilmektedir (Corey, 2008). Günümüzde insanı etkileyen ve varoluşsal boşluk veya anlamsızlık olarak nitelendirirlen durumları bireylerin yaşamasına neden olan bir takım ekonomik, sosyolojik ve psikolojik faktörler bulunmaktadır. İnsanoğlunun yönetmeye çalıştı̆ı birçok yaşamsal sorunlarla birlikte yaşam kaliteleri de düşmektedir. Bireyler bu yoğun karmaşa nedeniyle varoluşsal meseleleri düşünmeye, yaşamın anlamını aramaya ve bulmaya firsat bulamamaktadırlar. Tarım toplumundan sanayi toplumuna geçişle birlikte anlamsızlık bireylerin yoğun bir şekilde yaşadığı önemli sorunlardan biri haline gelmiştir (Geçtan,1990; Frankl, 2015; Yalom, 2013).

Yaşamda anlam kavramı, literatürde sıklıkla V. Frankl’ın logoterapi ile ilgili açıklamalarında göze çarpmaktadır. Nitekim Frankl logoterapi kuramını bu kavram çerçevesinde şekillendirmiştir. Frankl (2009), yaşamda anlamın olmayışını anlamsızlık olarak ifade etmiştir. Anlamsızlık, bireyi varoluşsal anlamda boşluğa götüren bir olgudur. Frankl varoluşsal boşluğu; bireyin can sıkıntısı, duygusuzluk, duyarsızık yaşaması yoluyla ne yapacağını bilememesi ve yaptıklarının amacını sorgulaması durumu olarak tanımlamakla birlikte; yaşamda anlamsızlık olgusu ile ruh sağlığı arasında olumsuz yönde ilişki olduğunu iddia etmektedir. Anlam, amaç, değer ve idealden yoksun olarak yaşayan bireyler yadsınamaz ölçüde stres ve psikolojik sıkıntılar yaşamaktadırlar (Frankl, 2009; Yalom, 2013; Sayar, 2014). Bu bağlamda yaşamda anlama sahip olmanın, insanların hayatında önemli bir rolü olduğu görülmektedir.

İnsanlar, hayatın anlamını sorgulamayı varoluşlarından itibaren sürdürmektedirler. Yalom'a (2013) göre anlam arayışı, tutarlııık arayışını ifade eder. Bu yüzden bireyler davranışlarının genellikle bir amaca hizmet etmesi için anlam arayışı içerisindedirler. Buna göre insanoğlunun hayatını belli bir doğrultuda yaşamak istediği görülmektedir. Ayrıca insanın yaşamda anlama sahip olması, hayatına devam edebilmesi adına temel güdüleyici bir faktör olarak görülmektedir ki Frankl insanın temel güdüsünün anlam arayışı olduğuna vurgu yapmaktadır (Frankl, 2009). Anlamsızlık, bireylerin kendilerini yönsüz, hedefsiz ve plansız veya çözüm üretmede eksik olarak algıladıklarında ortaya çıkmaktadır (Harlow ve Newcomb, 1990). Bu bağlamda düşünüldüğü zaman birey için yaşamda anlamın varlığııı; bireyin hayatının yaşanabilir olması ve davranışlarının yönünü belirlemesi adına bir pusula işlevinde olduğu görülmektedir.

Das'a (1998) göre yaşamda anlamın mevcudiyeti bireylerin yaşamlarında önemli işlevlere hizmet eder. Yaşamda anlam öncelikle hayatlarımız için bir amaç oluşturur, eylemlerimizi yargılamamıza yardımcı olur ve hayatımızdaki olaylarla ilgili kontrol hissi sağlar. Bu doğrultuda düşünüldüğü zaman yaşamda anlamın olmayışının bireyleri psikolojik yönden olumsuz etkilediği ve yaşamlarında bir anlam oluşturamayan bireylerin davranışlarını ezbere dayalı olarak sergiledikleri ve davranışlarının amacını sorguladıklarında boşluğa düştükleri söylenebilir. Aynı zamanda yaşamın anlamı bir ihtiyaç olarak da tanımlanmaktadır. Wubbolding'e (2015) göre gerçeklik terapisinin iddia ettiği insanın beş temel ihtiyacına (hayatta kalma, ait olma, içsel kontrol veya güç, özgürlük veya otonomi, eğlence) ek olarak maneviyat ve anlam da bir ihtiyaç olarak eklenebilir. Frankl’a (2009) göre yaşamda anlamı bulan insanlar zor koşullarda dayanıklılık gösterirler. Nitekim Frankl, Auschwitz 'de toplama kampı anılarını anlatırken, kamptaki mahkumların hayatta kalma becerilerinde fiziksel güçten ziyade anlam ihtiyacını ön plana çıkarır.

Insanlar yaşamda anlamı bulma, kendini ve dünyayı anlama çabasında farklı referanslara dayanırlar. Steger, Kashdan, Sullivan ve Lorentz'e (2008) göre anlam arayışı farklı insanlarda farklı temel motivasyonlardan kaynaklanabilir. Maneviyat veya spiritüellik bireyin hayat anlamlandırmasında sıklıkla kullandığı bir yoldur. İnsanoğlunun tarihini araştran bir araştrrmacı, maneviyatın gücünü yadsıyamaz çünkü semavi bir din, hümanizm veya doğada bir şeye duyulan inanç düşünüldüğünde, insanlar tarih boyunca manevi ve aşkın bir şeye inanma ihtiyacını hep duymuştur (Litwack, 2007). Spiritüellik neredeyse bütün çağlarda ve topluluklarda karşılaşılan bir olgudur. Spiritüelliğin, tüm dinler ve kültürlerde ifade edilebilen ortak bir insan paydasıdır (Helminiak, 2001). Bu durum da spiritüelliğin evrensel bir boyutu olduğunu göstermektedir.

Spiritüellik son zamanlarda birçok araştırmacı tarafindan incelenmiş ve tanımı hususunda tartş̧malar yaşanmıştır. Helminiak (2001) spiritüelliği, bireyin elinden gelenin en iyisi olmanın peşinde olması ve rehberlik edenin bireyin kendi içinde olduğuna dair bir ön kabul şeklinde tanımlar. Bu tanıma göre yaşamın anlamını bulmaya dair güç insanın içindedir. Myers'e (1990) göre ise spiritüellik, hayatta devam eden bir anlam ve amaç arayışı; hayatın derinliğini, evrenin genişliğini, işlev gören doğal güçleri anlama çabası olarak tanımlanır (Akt., Kardaş, 2017). Bu tanımda ise spiritüelliğin, hayatta anlam ve amaç arama ve bulma çabası ile gerçekleşebileceği söylenmektedir. Bir başka tanımda ise spiritüellik, hayatın materyal yönünün üstünde bir güç ve evrene dair köklü bir bağlılık duygusunu içeren insan varoluşunun bir özelliği olarak tanımlanmaktadır (Myers, Sweeney ve Witmer, 2000). Genellikle spiritüellik ve din kavramları birbiri ile 
karıştırılmakta ve birbirlerinin yerlerine kullanılmaktadır. Spiritüellik genellikle dini inançla eş anlamda kullanılır; ancak spiritüellik insanların hayatlarını nihai anlam katmalarına yarayan ve kişisel değerlerine göre hayatı anlamlandırdığı daha geniş ve daha kapsamlı bir tanımdır (Bekelman ve ark., 2007). Spiritüel iyi oluş ise; spiritüel gelişimin peşinde olma veya spiritüel gelişmeye dair dengeli bir açıklık hali, başkalarıyla iletişim kurma, yaşamda anlam ve hedefe sahip olma ve yüce bir güce inanç ve o güçle ilişki kurma duygusu olarak tanımlanabilir (Hawks ve ark., 1995). Spiritüel iyi oluş, bireyin algılanan yaşam kalitesinin önemli bir göstergesi olarak görülmektedir. Ellison’a (1983) göre spiritüel iyi oluş, psikososyal ve dini bir unsur da içerir. Spiritüel iyi oluş, kişiler arasında uyumlu ve entegre bir ilişki oluşmasına yardımcı olurken, bireyin hayatında istikrar, barış, uyum özelliklerinin gelişmesini sağlayarak kişinin kendisiyle, ilahıyla ve toplumuyla yakınlık duygusunu arttırır (Mahdian \& Ghaffari, 2016). Bu sayede birey, kişisel anlamda esenlik sağlarken; toplumsal anlamda da uyumlu davranışlar gösterir.

Maneviyat kavramı, DSM-IV'e manevi, dini problemlerin eklenmesi ve ayrıca psiko-manevi müdahalelere artan ilgi ile birlikte, etkin bir büyüme, ruh sağlığının iyiliği ve gelişim için oldukça önemli görülmektedir (Kasapoğlu, 2017). Shahidi ve Hamdie'nin (2002) yaptıkları araştırmalar sonucu, spiritüel iyi oluş düzeyi yüksek olan insanların daha sağlıklı bir hayat tarzına sahip olduklarını, daha mutlu olduklarını ve hayatlarından daha fazla memnun olduklarını göstermiştir (Akt., Mahdian, \& Ghaffari, 2016). Spiritüel yönelim bireyi; anlama, aşkınlığa, umuda ve sevgiye götürmektedir (Çelimli ve Güldal, 2016). Buna göre spiritüel iyi oluşun; hayat memnuniyeti, umut düzeyi gibi değişkenlerle yakından ilişkili olduğu görülmektedir. Bu değişkenlerin bireyin psikolojik iyi oluşunu ve sorunlara karşı psikolojik dayanıklılığını arttıracağı bu açıklamalardan anlaşılmaktadır.

Psikolojik dayanıklılık kavramı son yıllarda, özellikle de pozitif psikoloji literatüründe, sıklıkla göze çarpan kavramlardan biri olmuştur. Seligman ve Csikszentmihalyi'ye (2000) göre; pozitif psikoloji akımı, insanoğlunu etkiye tepki gösteren pasif bir organizma değil, karar veren, seçenekleri ve tercihleri olan sıkıntılı, umutsuz, yardımsız durumları yönetebilecek ve bu durumlarda dahi verimli olabilecek potansiyele sahip bireyler olarak tanımlar. Özellikle 21. yüzyılda insanın olumlu ve güçlü yönlerine odaklanan pozitif psikolojinin gelişmesi ile birlikte psikolojik dayanıklılık ile ilgili çalışmalar literatürde oldukça yaygınlaşmıştır. Günümüz dünyasında bireyler oldukça yoğun tempoda çalışmakta ve stres verici uyaranlara fazlaca maruz kalmaktadırlar. Bu durum da bireyleri psikolojik anlamda olumsuz etkilemektedir. Karşılaşılan sorunlar karşısında psikolojik dayanıklılığın yüksek olması; bireylerin kendilerini gerçekleştirmeleri, yaşamlarında olumlu, istendik ve çevrelerine uyumlu davranışlar sergilemeleri açısından oldukça önemli görülmektedir. Kobasa (1979) psikolojik dayanıklılığın stresli yaşam olayları karşısında, kişinin stresli durumları değerlendirmesini ve etkili başa çıkma becerileri geliştirmesini kolaylaştırdığını ifade etmiştir.

Psikolojik dayanıklılık genel olarak bireyin zorluklara uyum sağlama süreci, stresli yaşam olaylarına karşı bir direnç kaynağı ve olumlu bakış açısı kazanabilme becerisi olarak tanımlanmaktadır (Kobasa, 1979; Cencirulo, 2001; Hunter 2001; Tusaie ve Dyer, 2004). Ancak literatüre bakıldığında psikolojik dayanıklılığa dair ortak bir tanımın olmayışı göze çarpmaktadır. Bu nedenle tanımlardaki ortak temalara bakıldığı zaman psikolojik dayanıklılığın açıklanmasında bireyin zorlu hayat şartlarına uyum sağlama ve onunla etkili bir şekilde başa çıkabilme becerisinden söz edebiliriz. Psikolojik dayanıklılık, önemli bir sıkıntı bağlamında olumlu adaptasyonu içeren dinamik bir süreci ifade eder (Luthar, Cicchetti \& Becker, 2000). Walsh’a (2006) göre, psikolojik dayanıklılık sayesinde birey yaşadığı acıyı iyileştirir, yaşamında daha çok sorumluluk alır, hayatını daha dolu yaşar ve yaşamını sevgi ile sürdürebilir (Akt., Parlak, 2014). Psikolojik dayanıklılık düzeyi yüksek olan bireylerin stres oluşturan durumları uyum sağlayıcı bir süreç olarak değerlendirdikleri ve etkili başa çıkma stratejilerini kullanarak fiziksel ve ruhsal açıdan sağlıklarını korudukları görülmektedir (Işık, 2016). Bu nedenle bireylerin yaşamda karşılaştıkları problemleri atlatıp, bir an önce yaşama adapte olabilmeleri için sahip oldukları psikolojik dayanıklılık düzeylerinin önemli rolü vardır. Nowack (1986) psikolojik dayanıklılığı yüksek bireylerin A tipi kişilik özelliğine sahip, sağlıklı alışkanlıkları olan ve yaşama olumlu bakan bireyler olduklarını söyler. Psikolojik anlamda dayanıklı bireylerin, problem çözme becerisine sahip, içten denetim odaklı, özsaygısı yüksek, kişilerarası ilişkileri gelişmiş, olumlu kişilik özellikleri taşıyan, zorluklar karşısında yılmayan, zorluklara rağmen kendini geliştiren ve empati kurma yeteneğine malik bireyler olduğu kabul edilmektedir (Vergili, 2018). Bazı araştırmacılar bireylerin psikolojik dayanıklılığa dair genetik avantajlara sahip olduklarını iddia etse de çoğu araştırmacı psikolojik dayanıklılık özelliklerinin bireyler tarafindan süreç içerisinde geliştirilebileceğini söyler. Psikolojik dayanıklılık, kişilik özelliğinden daha çok, dinamik bir süreci kapsamaktadır (Luthar, Cicchetti \& Becker, 2000). Hem genetiğin hem de çevrenin kişilik gelişimine katkısı olduğu bilindiğinden; bir kişilik özelliği olarak psikolojik dayanıklılık için doğuştan getirilen avantajlar olsa da bu özelliğin sonradan da geliştirilebileceği söylenebilir. Zira Glantz ve Sloboda' ya (1999) göre; psikolojik dayanıklılık ne bütünüyle bireyin karakteristik özelliklerine ne de çevrenin etkisine bağlıdır; psikolojik dayanıklılık bireysel ve çevresel etmenlerin etkileşiminin bir sonucudur.

| Kastamonu Eğitim Dergisi, 27(4), 2019| 
Zorluklar karşısında yılmamak, dayanıklı olmak için insanın bir nedene sahip olması gerekmektedir. Birey yaşamın anlamını arayarak ve bularak bu nedeni oluşturur. Yaşadığı sıkıntılar karşısında ayakta kalmayı başaran psikolojik dayanıklılığı yüksek bireyler; bireysel amaçları ve daha anlamlı yaşama sahip olma hedefi olan bireylerdir (Terzi, 2016). Yaşamında bir anlama sahip bireylerin yaşadıkları zorlukları daha rahat atlatabildikleri ve psikolojik dayanıklılıklarının yüksek oldukları düşünülmektedir. Parlak'ın (2014) Kredi Yurtlar Kurumu'nda kalan kız öğrenciler üzerinde yaptığı araştırmada psikolojik dayanıklıık ile yaşamda anlam düzeyi arasında olumlu yönde anlamlı bir ilişki olduğu ortaya çıkmıştr. Ayrıca Kobasa'nın tanımladığı dayanıklı bireyin özellikleri ile varoluşçu yaklaşımın görüşleri örtüşmektedir (Terzi, 2005). Varoluşçu yaklaşımın önemli kavramlarından olan yaşamda anlam ile pozitif psikolojinin önemli kavramlarından psikolojik dayanıklılık arasında bu bağlamda anlamlı bir ilişki olacağı düşünülmektedir. Ayrıca spiritüel anlamda iyi oluş düzeyi yüksek bireylerin de psikolojik anlamda zorlukların üstesinden daha rahat gelebileceği tahmin edilmektedir. Kamya'nın (2000) sosyal hizmet öğrencilerinin psikolojik dayanıklılıkları ile spiritüel iyi oluş düzeyleri arasında yaptığı araşttrmada iki değişken arasında anlamlı bir ilişki bulunmuştur. Bu araştrmalar bağlamında düşünüldüğü zaman spiritüel iyi oluş, yaşamda anlam ve psikolojik dayanıklılık değişkenleri arasında anlamlı bir ilişki olması beklenmektedir. Yapılan araştrrmalar ve ilgili alan literatürünün bu söylemlerine bakıldığında bireylerin hem yaşamdaki anlam düzeylerinin hem de spiritüel iyi oluşlarının psikolojik dayanıklılıkları üzerinde etkisi olduğu ileri sürülebilir. Alanda yapılan çalışmalar incelendiğinde eğitim hizmet alanının en önemli öğesi olarak görülen öğretmenler veya öğretmen adaylarıyla bu değişkenleri ele alan bir araştırmaya rastlanmamıştır. İş yaşamında fazlaca stresli yaşam olayına maruz kalma potansiyeli olan ve psikolojik dayanıklılığa bu anlamda sahip olması beklenen öğretmen adayları bu nedenle çalışmada örneklem olarak ele alınmıştır. Yukarıda bahsedilen değişkenlerle ilgili açıklamalar çerçevesinde, değişkenler arasında öngörülen ilişkilerden hareketle; bu araştırmanın amacı öğretmen adaylarının spiritüel iyi oluş ve yaşamda anlam düzeylerinin, psikolojik dayanıklılık düzeyini yordama gücünün yapısal eşitlik modeli (YEM) aracılığıyla incelenmesidir. Bu doğrultuda araştırmanın problem cümlesi "Yaşamda anlam ve spiritüel iyi oluş düzeylerinin öğretmen adaylarının psikolojik dayanıklılık düzeylerini anlamlı düzeyde yordamakta mıdır?” olarak belirlenmiştir. Benzer çalışma sayısının oldukça az olması nedeniyle yapılan bu araştırmanın sonuçlarının, benzer değişkenler ile ilgili gelecekte yapılacak araştırmalara ışık tutması beklenmektedir. Ayrıca çalışmanın, eğitim bilimleri alanının rehberlik ve psikolojik danışmanlık dışındaki farklı disiplinleri için de önemli olduğu düşünülmektedir.

\section{Yöntem}

Bu bölümde araştırma modeli, evren ve örneklem, veri toplama araçları, verilerin analizine ilişkin bilgiler yer almaktadır.

\section{Araştırma Modeli}

Araştırmada korelasyonel model kullanıımıştır. Korelasyonel model; iki veya daha fazla değişken arasındaki ilişkinin değişkenlere müdahale edilmeksizin incelendiği nicel tür araştırma desenidir (Büyüköztürk, Kılıç-Çakmak, Akgün, Karadeniz, Demirel, 2012). Bu araştırmada spiritüel iyi oluş ve yaşamda anlam düzeylerinin psikolojik dayanıkılık üzerindeki yordama gücü incelendiği için, korelasyonel model türlerinden yordayıcı korelasyonel araştırma deseni kullanılmıştır.

\section{Evren ve Örneklem}

Bu araştırmada genel evrene ulaşmanın zorlukları nedeniyle çalışma evreni kullanılmıştır. Bu doğrultuda araştırmanın çalışma evreni, 2017-2018 öğretim yılı bahar döneminde Marmara Üniversitesi Atatürk Eğitim Fakültesinde formasyon programlarına devam eden 3327 bireyden oluşmaktadır.

Araştırma örnekleminin belirlenmesinde, örneklemin alındığı evreni temsil etmesi önemli görülmektedir. Yazıcıŏlu ve Erdoğan' ın (2004) \%5 hata payı için örneklem büyüklükleri tablosu referans alındığında araştırmanın örneklem büyüklüğü homojen yapıda olmayan evren için \%95 güven aralığında 344 kişi olarak belirlenmiştir. Olası veri kayıpları da göz önüne alınarak 380 katılımcıya ulaşılmıştır.

Araştırmada örnekleme türü olarak çok aşamalı küme örnekleme yöntemi uygulanmıştır. Öncelikle tabakalı örnekleme yöntemine bağlı olarak, üniversiteye yerleşmede etkili olan puan türü dikkate alınmış ve her puan türü tabaka olarak kabul edilerek toplamda 6 tabaka oluşmuştur. Daha sonra her tabakaya ait programlar küme olarak belirlenmiş olup her tabakadan tesadüfi küme örnekleme ile uygulama yapılacak öğrenciler belirlenmiştir. Uygulanan bu yöntem sayesinde Atatürk Eğitim Fakültesi Pedagojik Formasyon farklı programlarında öğrenim gören öğrenciler araştırma kapsamına dahil edilerek veri seti zenginleştirilmiştir. Örneklemi oluşturan öğrenciler için tesadüfi küme örnekleme yapılırken araştrmaya dahil olan programlar; İngilizce Öğretmenliği, Din Kültürü ve Ahlak Bilgisi Öğretmenliği, Türk Dili ve Edebiyat Öğretmenliği, Beden Eğitimi Öğretmenliği, Resim Öğretmenliği, Felsefe Öğretmenliği ve Tarih Öğretmenliği'dir. Kümeler belirlendikten sonra seçilen her kümenin evrendeki oranına göre ulaşılacak öğrenci sayısına karar verilmiştir. 


\section{Veri Toplama Araçları}

Araştırmada veri toplama aracı olarak Yaşamda Anlam Ölçeği, Spiritüel İyi Oluş Ölçeği ve Psikolojik Dayanıklılık Ölçeği kullanılmıştr. Katılımcılara ait kişisel bilgiler araştırmacı tarafindan oluşturulan Kişisel Bilgi Formu ile toplanmıştır.

Kişisel Bilgi Formu: Araştırmanın katılımcıları hakkında gerekli kişisel bilgileri toplamak amacıyla hazırlanan Kişisel Bilgi Formu'nda katlımcıların cinsiyetleri, yaşları, okudukları bölüm, sınıf düzeyleri, ebeveyn eğitim düzeyleri ve algıladıkları sosyoekonomik düzeyleri hakkında sorular yer almaktadır.

Spiritüel lyi Oluş Ölçeği: Ölçek Ekşi ve Kardaş (2017) tarafindan geliştirilmiştir. Spiritüel İyi Oluş Ölçeği yetişkinlere yönelik geliştirilmiş 29 maddelik 5'li likert tipinde bir ölçektir (1= Bana hiç uygun değil, 4= Bana tamamen uygun). Spiritüel iyi oluş ölçeği aşkınlık, doğayla uyum ve anomi olmak üzere 3 alt boyut içermektedir. Ölçekten toplam puan alınmak istenirse anomi alt boyutundaki maddelerin ters puanlanması gerekmektedir. Ölçeğin alt boyutlarının güvenirlik katsayılarına bakıldığında; aşkınlık alt boyutuna ait Cronbach's Alpha değeri $\alpha=, 953$, doğayla uyum alt boyutu için $\alpha=, 864$ ve anomi alt boyutu için ise $\alpha=, 853$ olarak bulunmuştur. Bununla birlikte ölçeğin toplam Cronbach's Alpha değeri ise $\alpha=, 886$ olarak hesaplanmıştir.

Psikolojik Dayanıkııık Ölçeği: Ölçek Terzi (2013) tarafindan geliştirilmiştir. Psikolojik Dayanıklılık Ölçeği; meydan okuma, kendini adama ve kontrol olmak üzere 3 alt boyuttan oluşmaktadır. Ölçeğin 2. ve 15. maddeleri ters puanlanmaktadır. Ölçek 21 maddeden oluşmakta olup 5'li likert tipindedir ( $0=$ Hiç katılmıyorum, 4= Kesinlikle katlıyorum). Ölçeğin toplam güvenirlik katsayısı .76, kendini adama alt boyutu için .62, kontrol alt boyutu için .69, meydan okuma alt boyutu için .74 olarak bulunmuştur. Test-tekrar test güvenirliği .81 bulunmuştur.

Yaşamda Anlam Ölçeği: Steger, Frazier, Oishi ve Kaler (2006) tarafindan geliştirilen bu ölçek, Demirbaş (2010) tarafindan Türkçeye uyarlanmıştır. Yaşamda anlam ölçeği yaşamda anlam varlığı ve yaşamda anlam aranması olmak üzere 2 alt boyuttan oluşmaktadır. 10 maddeden oluşan ölçek 7'li likert tipindedir (1= Kesinlikle doğru değil, 7= Kesinlikle doğru). Ölçeğin 9. maddesi ters maddedir. Ölçekte toplam puan alınmamaktadır; her alt boyut kendi içerisinde değerlendirilmektedir. Ölçeğin tamamına ilişkin iç-tutarlık güvenirlik katsayısı .86 olarak bulunmuştur. Yaşamda anlamın varlığı alt boyutunun içtutarlığı .87, yaşamda anlam arayışı alt boyutunun iç-tutarlığı .88 olarak hesaplanmıştr.

\section{Verilerin Analizi}

Elde edilen verilerin analizinde SPSS 21.0 istatistik paket programı ve AMOS 20.0 programı kullanılmıştr. Hatalı doldurulan 18 ve uç değerlere sahip 24 ölçek veri setinden çıkarılarak analize başlanmıştr. Analizlerde değişkenler arasındaki ilişkiyi saptamak amacıyla Pearson korelasyonu, değişkenlerin birbirlerini açıklama güçlerini saptamak için yapısal eşitlik modeli kullanılmıştr. Analizlerle ilgili verilere bulgular bölümünde yer verilmiştir.

\section{Bulgular}

Katılımcıların spiritüel iyi oluş, yaşamda anlam ve psikolojik dayanıklılık düzeyleri arasındaki ilişkiyi belirlemek amacıyla yapılan Pearson Momentler Çarpımı Korelasyonu sonuçları Tablo 1' de gösterilmektedir.

Tablo 1. Spiritüel İyi Oluş, Yaşamda Anlam ve Psikolojik Dayanıklılık Düzeyi Puanları Arasındaki ilişkinin İncelenmesi

\begin{tabular}{lccc}
\hline & 1 & 2 & 3 \\
\hline Spiritüel İyi Oluş (1) & 1.00 & & \\
Yaşamda Anlam (2) & $.27^{* *}$ & 1.00 & \\
Psikolojik Dayanıklılık (3) & $.45^{* *}$ & $.25^{* *}$ & 1.00 \\
\hline
\end{tabular}

$* * p<.001$

Tablo 1' de görüldüğü üzere, örneklem grubunu oluşturan bireylerin spiritüel iyi oluş düzeyleri, yaşamda anlam düzeyleri ve psikolojik dayanıklılık düzeyleri arasında anlamlı bir ilişki bulunup bulunmadığını belirlemek amacıyla yapılan Pearson analizi sonucunda spiritüel iyi oluş ile yaşamda anlam düzeyleri arasındaki ilişki $(r=.27 ; p<.001)$; spiritüel iyi oluş ile psikolojik dayanıklılık düzeyleri arasındaki ilişki $(r=.45 ; p<.001)$ ve yaşamda anlam ile psikolojik dayanıkııık düzeyleri arasındaki ilişki $(r=.25 ; p<.001)$ pozitif yönde anlamlı bulunmuştur.

Elde edilen bu anlamlı ilişkilerin ardından yapısal eşitlik modeli ile değişkenler arasındaki yapısal ilişkilerin analizine geçilmiştir. Yapısal eşitlik modeli (YEM), değişkenler arasındaki doğrudan ve dolaylı etkilerin birlikte analiz edilmesine imkan veren istatistiksel bir yöntemdir (Bayram, 2011). Yapısal eşitlik modeli (YEM), değişkenler arasındaki doğrusal 
ilişkilerin hatadan arınmış olarak hesaplanmasını sağladığı için regresyon ve yol analizine göre daha güvenilir sonuçlar vermektedir (Meydan ve Şeşen, 2011). Analizlere başlamadan önce değişkenler arasındaki ilişkileri açıklamaya çalışan alan literatüründen yararlanılmıştır. Örneğin, Işık'ın (2016) elde ettiği verilere göre psikolojik dayanıklılı̆ın alt boyutları olan meydan okuma, kontrol ve kendini adama hem kendi aralarında hem de ölçekten elde edilen toplam puanla olumlu ve anlamlı ilişkiler göstermektedir. Modelden elde edilen bulgular da bu olumlu ve anlamlı ilişkileri desteklemektedir. Parlak'ın (2014) Kredi Yurtlar Kurumu'nda kalan kız öğrenciler üzerinde yaptığı araştırmada psikolojik dayanıklılık ile yaşamda anlam düzeyi arasında; Mahdian ve Ghaffari' nin (2016) kanser hastalarının katılımı ile yapmış oldukları araştırmada ise spiritüel iyi oluş ile psikolojik dayanıklılık arasında olumlu yönde anlamlı bir ilişki bulunmuştur. Bu çerçevede yapısal modelin kurulmasında spiritiüel iyi oluş ve yaşamda anlam değişkenleri yordayıcı değişkenler, psikolojik dayanıkııık ise yordanan değişken olarak ele alınmıştır.

\section{Şekil 1. Modele Yönelik Yapısal Eşitlik Modeli}

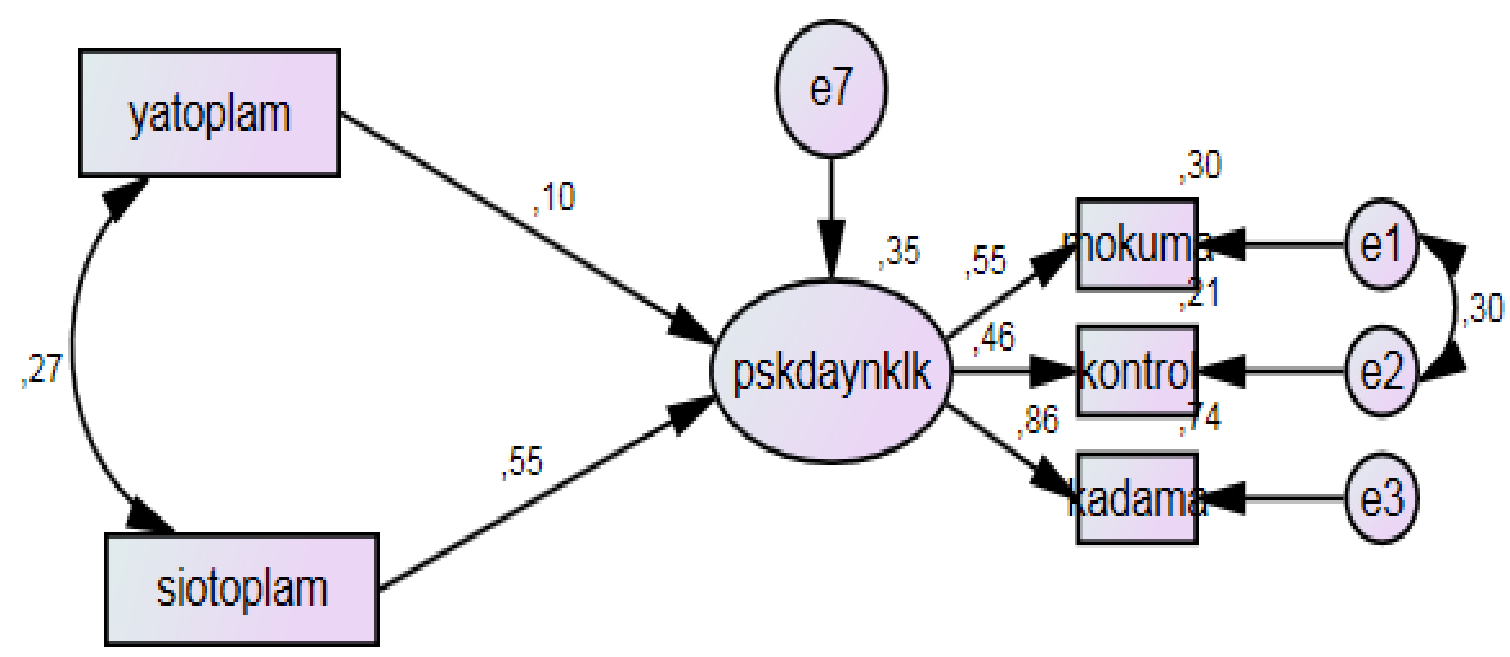

Şekil 1' de görüldüğü üzere, spiritüel iyi oluş ve yaşamda anlam değişkenlerinin psikolojik dayanıklılık değişkenini anlamlı bir şekilde açıkladığı tespit edilmiştir. Psikolojik dayanıkııık değişkeninin toplamda \%35' lik kısmının yaşamda anlam ve spiritüel iyi oluş değişkenleri tarafindan açıklandığı görülmektedir. Ayrıca kurulan modele göre, psikolojik dayanıklıık değişkenindeki varyansın \%10' unu yaşamda anlam değişkeni; \%55' ini ise spiritüel iyi oluş değişkeni açıklamaktadır. Elde edilen modelin uyum değerleri ise Tablo 2' de verilmiştir.

Tablo 2. Yapısal Eşitlik Modelinin Uyumuna Yönelik İstatistiksel Değerler

\begin{tabular}{|c|c|c|c|}
\hline Model Uyum Kriteri & İyi Uyum & Kabul Edilebilir Uyum & Mevcut Çalışma \\
\hline $\mathrm{X}^{2}$ Uyum testi & $0,05<p \leq 1$ & $0,01<p \leq 0,05$ & 013 \\
\hline CMIN/SD & $X^{2} / s d \leq 3$ & $X^{2} / s d \leq 5$ & 3,59 \\
\hline $\mathrm{IFI}$ & $0,95 \leq|F|$ & $0,90 \leq|F|$ & ,98 \\
\hline $\mathrm{CFI}$ & $0,97 \leq \mathrm{CFI}$ & $0,95 \leq \mathrm{CFI}$ & ,98 \\
\hline RMSEA & RMSEA $\leq 0,05$ & RMSEA $\leq 0,08$ & ,08 \\
\hline GFI & $0,90 \leq \mathrm{GFI}$ & $0,85 \leq \mathrm{GFI}$ & ,99 \\
\hline
\end{tabular}

Tablo 2' de uyum iyiliği indekslerine bakıldığında; modelin kabul edilebilir düzeyde anlamlı olduğu görülmektedir $(p \leq, 05) \cdot X^{2}$ Uyum testi değerlerine bakıldığında ise modelin orta düzeyde uyum gösterdiği görülmektedir ( $X^{2} U y u m$ testi $=, 013$ ). Diğer uyum iyiliği indekslerinden RMSEA değerine bakıldığında ise, evren ve örneklem arasında kabul edilebilir bir uyum olduğundan söz edilebilir (RMSEA $=0,08$ ). Modele ilişkin CFI değeri ise iyi bir uyumu yansıtmaktadır 
(CFI= ,98). Bir diğer uyum iyiliği indeksleri ise GFI ve IFI değerleridir. Bu araşttrmadaki GFI ve IFI değerleri, modelde iyi bir uyumun olduğunu göstermektedir ( $\mathrm{GFI}=, 99 ; \mathrm{IFI}=$,98). Söz konusu uyum iyiliği indekslerine bakılarak, geliştirilen modelin veri ile tüm uyum iyiliği indeksleri bakımından istatistiksel anlamda iyi veya kabul edilebilir uyuma sahip olduğu sonucuna varılabilmektedir.

\section{Sonuçlar}

Bu araştırmanın ana amacı, spiritüel iyi oluş ve yaşamda anlamın psikolojik dayanıklılığı yordama gücünü saptamaktır. Araştırmanın bulgularına göre spiritüel iyi oluş, yaşamda anlam ve psikolojik dayanıklılık değiş̧kenleri arasında anlamlı pozitif ilişkiler bulunmaktadır. Başka bir ifadeyle, öğretmen adaylarında spiritüel iyi oluş ve yaşamda anlam düzeyleri arttkça psikolojik dayanıklılık düzeyleri de artmaktadır. Yine araştırma bulgularına göre, kurulan yapısal eşitlik modelinde hem yaşamda anlamın hem de spiritüel iyi oluşun, bireylerin psikolojik dayanıkları üzerinde önemli yordayıcı etkileri olduğu görülmektedir. Elde edilen bulgular hem alan literatürü ile hem de yapılmış sınırlı sayıdaki diğer çalışma bulguları ile örtüşür niteliktedir. Spiritüel iyi oluş kavramı, alanda en çok ruh sağlığı bağlamında ele alınan bir kavram olmuştur. Bireyin manevi olarak iyi olmasının psikolojik olarak da sağlıklı olmasına katkı sağlayacağı ifade edilmektedir. Bu bakış açısına göre "olumlu özelliklere sahip olunması, olumsuz özelliklerden uzak durulması" ruhen sağılılı olmanın yanı sıra iyilik halinin de göstergesi olarak kabul edilmiştir (Ventis, 1995). Spiritüel yönelim bireyi; anlama, aşkınlığa, umuda ve sevgiye götürmektedir (Çelimli ve Güldal, 2016). Bu bağlamda düşünüldüğünde spiritüel iyi oluşun, hem günümüzün en büyük intiyaçlarından biri olarak tanımlanan (Sayar, 2014) yaşamda anlam düzeyini hem de psikolojik dayanıklılığı etkileyecek bir değişken olabileceği görülmektedir. Psikolojik dayanıklılık ise bireyleri hayattaki zorluklara karşı ayakta tutan dinamiklerden biri olarak görülmektedir. Kobasa (1979), psikolojik dayanıklılı̆ı stresli yaşam olaylarına karşı bir direnç kaynağı ve koruyucu kalkan işlevi gören kişisel bir özellik olarak görmektedir. Bu anlamda Kobasa (1979)'un tanımladığı psikolojik anlamda dayanıklı bireylerin özellikleri ile varoluşçu yaklaşımın yaşamda anlam ve spiritüel iyi olma ile ilgili görüşlerinin örtüştüğü görülmektedir.

Alanda yapılan çalışmalar incelendiğinde bu üç değiş̧keni bir arada ele alan araştırmaya rastlanmamakla beraber, değişkenlerin ayrı ayrı ilişkilerinin incelendiği veya bu değişkenlerle yüksek ilişkili başka değişkenlerle ele alındığı göze çarpmaktadır. Parlak'ın (2014) Kredi Yurtlar Kurumu'nda kalan kız öğrenciler üzerinde yaptı̆ı̆ araştırmada psikolojik dayanıklııık ile yaşamda anlam düzeyi arasında olumlu yönde anlamlı bir ilişki olduğu ortaya çıkmıştır. Benzer şekilde, Yıkılmaz ve Demir-Güdül (2015) yaptıkları araştrmada üniversite öğrencilerinin yaşamda anlam düzeylerinin psikolojik dayanıklılıkla yakından ilişkili bir kavram olan yaşam doyumunun anlamlı bir yordayıcısı olduğunu belirtmişlerdir. Demirbaş ve Keklik (2011), araştırmalarında psikolojik dayanıkılık ile yakından ilişkili bir kavram olarak ele alınan yılmazlık ve yaşamda anlam arasındaki pozitif ilişkilere dikkat çekmektedirler. Demirbaş-Çelik (2016) ise üniversite öğrencileri ile yürüttüğü çalışmasında yaşamda anlam değişkeni ile psikolojik sağığın bir göstergesi kabul edilen yaşam amaçları arasındaki pozitif korelasyona vurgu yapmaktadır. Yine üniversite örneklemi ile çalışılan başka bir araştrmada (Şahin, Aydın, Sarı, Kaya ve Pala, 2012); umut ve yaşamda anlam değişkenlerinin, psikolojik dayanıklılık ile yüksek ilişki gösteren öznel iyi oluşun anlamlı yordayıcıları olduğu görülmektedir. Kamya'nın (2000) sosyal hizmet öğrencilerinin psikolojik dayanıklılıkları ile spiritüel iyi oluş düzeyleri arasında yaptığı araştırmada iki değişken arasında anlamlı bir ilişki bulunmuştur. Ayrıca Shahidi ve Hamdie' nin (2002) yaptıkları araştırmalar sonucunda, spiritüel iyi oluş düzeyi yüksek olan insanların daha sağlıklı bir hayat tarzına sahip olduklarını, daha mutlu olduklarını ve hayatlarından daha fazla memnun olduklarını göstermiştir (Akt., Mahdian \& Ghaffari, 2016). Mahdian ve Ghaffari (2016) kanser hastalarının katılımı ile yapmış oldukları araştırmada; spiritüel iyi oluş ile psikolojik dayanıklılık arasında olumlu yönde anlamlı bir ilişki bulmuşlardır. Tüm bu söylemler ve başka araştırma bulguları bu araştırmada test edilen modelin bulgularını destekler niteliktedir. Sonuç olarak, mesleğe başladıklarında birçok stresli yaşam olayına maruz kalma potansiyeli olan öğretmen adaylarının psikolojik dayanıklılıklarında hem spiritüel iyi oluşun hem de yaşamda anlam değişkeninin anlamlı birer yordayıcılar olduğu görülmektedir.

\section{5. Öneriler}

Alanyazın incelendiğinde bu araştırmada konu edinilen üç değişkeni bir arada bulunduran bir araştırmaya rastlanmamaktadır. Özellikle Türkçe alanyazın incelendiğinde; psikoloji, psikolojik danışmanlık ve rehberlik ve eğitim bilimlerinin diğer alanlarında spiritüellik, maneviyat veya yaşamda anlam ile ilgili yapılmış çalışmalara az rastlanmaktadır. Alanyazındaki boşluğa bakıldığında bu iki değişken arasında yapılacak çalışmalara ihtiyaç vardır. Psikolojik dayanıklılığın bireyin ruh sağlığında önemli bir işlevi olduğu düşünüldüğünde, psikolojik dayanıklılık ile ilişkili değişkenlerin incelenip tespit edilmesi önleyici ruh sağlığı hizmetlerinin gelişimi açısından önemli görülmektedir. Öte yandan olumlu psikolojik özellikleri yordama potansiyeline sahip bu değişkenlerle ilgili araştırmaların sayısının artmasının, söz konusu değişkenin 
etkisinin daha iyi anlaşılabilmesi adına araştırmacılara fikir vereceği düşünülmektedir. Bu araştırmanın bulguları Marmara Üniversitesi formasyon birimi öğrencileri ile sınırıdır; yapılacak olan diğer çalışmalarda farklı örneklem grupları üzerinde çalışmalar yapılması alana katkı sağlaması adına önemli görülmektedir. Ayrıca üniversite eğitiminde öğretmen adaylarının spiritüel anlamda iyi olabilmelerine ve yaşamlarına anlam katabilmelerine yardımcı olabilecek eğitim-öğretim ortamı sunulmasının, bu konularla ilgili psiko-eğitim çalışmalarının düzenlenmesinin bu bireylerin psikolojik dayanıklılığını arttırılması adına önemli olduğu düşünülmektedir.

\section{Kaynakça}

Bayram, N. (2011). Yapısal eşitlik modellemesine giriş. Ankara: Ezgi Kitabevi.

Bekelman, D. B., Dy, S. M., Becker, D. M., Wittstein, I. S., Hendricks, D. E., Yamashita, T. E. \& Gottlieb, S. H. (2007). Spiritual well-being and depression in patients with heart failure. Journal of General Internal Medicine, 22(4), 470-477. doi: 10.1007/ s11606-006-0044-9

Büyüköztürk, Ş., Kılıç Çakmak, E., Akgün, Ö. E., Karadeniz, Ş. ve Demirel, F. (2012). Bilimsel araştrma yöntemleri (7. Baskı). Ankara: Pegem Akademi.

Cencirulo, R. S. (2001) The relationship between hardiness and job satisfaction in elementary school teachers. (Unpublished doctoral dissertation). University of La Sierra, CA. Retrieved from Proquest Dissertations \& Theses Global database. (3012888)

Corey, G. (2008). Psikolojik danışma kuram ve uygulamaları (T. Ergene, Çev.). Ankara: Mentis.

Çelimli, Ç. ve Güldal, ş. T. (2016). Manevi yönelimli danışmanlık ile psikoterapi yöntem ve teknikleri: Doğu ve Bat’dan örnekler. H. Ekşi ve Ç. Kaya (Ed.), Manevi yönelimli psikoterapi ve psikolojik danışma içinde (s. 99-122). İstanbul: Kaknüs.

Das, A. K. (1998). Frankl and the realm of meaning. Journal of Humanistic Education and Development, 36, 199-211. Retrieved from Wiley Open Library database.

Demirbaş-Çelik, N. (2016). Üniversite öğrencilerinin yaşamda anlam ve yaşam amaçları arasındaki ilişki. Mediterranean Journal of Humanities, 6(1), 133-141.

Demirbaş, N., \& Keklik, i. (2011, Ekim). Üniversite öğrencilerinin yaşamda anlam düzeyleri ve yılmazlık düzeyleri arasındaki ilişki, XI. Ulusal Psikolojik Danışmanlık ve Rehberlik Kongresi. Ege Üniversitesi'nde yapılan kongre, İzmir.

Ellison, C. W. (1983). Spiritual well-being: Conceptualization and measurement. Journal of Psychology and Theology, 11, 330-340.

Frankl, V. E. (2009). Insanın anlam arayışı. (Çev. Budak, S.). İstanbul: Okuyan Us.

Geçtan, E. (2013). Varoluş ve psikiyatri. İstanbul: Metis.

Glantz, M. D. \& Sloboda, Z. (1999). Analysis and reconceptualization of resilience. M. D. Glantz, \& J. L. Johnson (Eds.), In resilience and development: Positive life adaptations (pp. 109-126). NY: Kluwer Academic.

Harlow, L. L., \& Newcomb, M. D. (1990). Towards a general hierarchical model of meaning and satisfaction in life. Multivariate Behavioral Research, 25(3), 387-405. doi: http://dx.doi.org/10.1207/s15327906mbr2503_9

Hawks, S. R., Hull, M., Thalman, R. L., \& Richins, P. M. (1995). Review of spiritual health: definition, role, and intervention strategies in health promotion. American Journal of Health Promotion, 9, 371-378.

Helminiak, D. A. (2001). Treating Spiritual Issues in Secular Psychotherapy. Counseling and Values, 45(3), 163-189. Retrieved from Wiley Open Library database.

Hunter AJ (2001). A cross-cultural comparison of resilience in adolescents. Journal Pediatric Nursing, 16(3),172-179. Retrieved from Science Direct database.

Işık, Ş. (2016). Psikolojik dayanıklııı ölçeği'nin geliştirilmesi: Geçerlik ve güvenirlik çalışması. The Journal of Happiness \& Well-Being, 4(2), 165-182.

Kamya, H. A. (2000). Hardıness and spiritual well-being among social work students: Implications for social work education. Journal of Social Work Education, 36(2), 231-240.

Kardaş, S. (2017). Sanal kimlik ve spiritüel iyi oluşun üniversite öğrencilerinin narsistik eğilimlerini yordayıcılı̆̆ı. (Doktora tezi). YÖK Tez Merkezi'nden edinilmiştir. (469572)

Kasapoğlu, F. (2017). Psikolojik danışma süreci ve maneviyat: Bir bütünleştirme arayışı. Hikmet Yurdu, 10(19), 141-157. doi: 10.17540/hikmet.2017.55

Kobasa, S. C. (1979). Stressful life events, personality, and health: an inquiry into hardiness. Journal of Personality and Social Psychology, 37(1). 1-17.

Litwack, L. (2007). Basic needs, a retrospective. International Journal of Reality Therapy, 24(2), 28-30.

Luthar, S. S., Cicchetti, D., \& Becker, B. (2000). The construct of resilience: A critical evaluation and guidelines for future work. Child Development, 71(3), 543-562.

Mahdian, Z. \& Ghaffari, M. (2016). The mediating role of psychological resilience, and social support on the relationship between spiritual well-being and hope in cancer patients. Journal of Fundamentals of Mental Health, 18(3), 130-138. 
Meydan, C.H. ve Şeşen, H. (2011). Yapısal eşitlik modellemesi AMOS uygulamaları. Ankara: Detay Yayıncılık.

Myers, J. E., Sweeney, T. J. \& Witmer, J. E. (2000). The wheel of wellness counseling for wellness: A holistic model for treatment planning. Journal of Counseling and Development, 78(3), 251-266.

Nowack, K. M. (1986). Type A, hardiness and psychological distress. Journal of Behavioral Medicine, 9(6), 537-548. Retrieved from SpringerLink database.

Parlak, S. (2014). Yüksek Öğrenim Kredi Yurtlar Kurumunda barınan kız öğrencilerin yaşam anlam düzeyleri ile psikolojik dayanıkIılıkları arasındaki ilişki (İstanbul örneği). (Yüksek lisans tezi). YÖK Tez Merkezi'nden edinilmiştir. (372322)

Terzi, Ş. (2005). Öznel iyi olmaya ilişkin psikolojik dayanıklılık modeli. (Doktora tezi). (159406)

Terzi, Ş. (2016). Üniversite öğrencilerinin psikolojik dayanıklııkları ve algıladıkları sosyal destek arasındaki ilişki. Türk Psikolojik Danışma ve Rehberlik Dergisi, 3(29), 1-11.

Tusaie, K. \& Dyer, J. (2004). Resilience: A historical review of the construct. Holistic Nursing Practice, 18(1), 3-8.

Sayar, K. (2014). Sufi psikolojisi. İstanbul: Timaş Yayınları.

Seligman, M. E., \& Csikszentmihalyi, M. (2000). Special issue on happiness, excellence, and optimal human functioning. American Psychologist, 55(1), 5-183.

Steger, M. F., Kashdan, T. B., Sullivan, B. A. \& Lorentz, D. (2008). Understanding the search for meaning in life: Personality, cognitive style, and the dynamic between seeking and experiencing meaning. Journal of Personality, 76(2). doi: 10.1111/j.14676494.2007.00484.x

Şahin, M., Aydın, B., Sarı, S. V., Kaya, S. ve Pala, H. (2012). Öznel iyi oluşu açıklamada umut ve yaşamda anlamın rolü. Kastamonu Eğitim Dergisi, 20(3), 827-836.

Ventis, W. L. (1995). The relationships between religion and mentalhealthy. Journal of Social Issue, 51(2), 33-48.

Vergili, M. (2018). Üniversite öğrencilerinde bağlanma biçimleri ile psikolojik dayanıklılık arasındaki ilişkinin incelenmesi. (Yüksek lisans tezi). YÖK Tez Merkezi'nden edinilmiştir. (486104)

Wubbolding, R. E. (2015). Gerçeklik terapisi (Çev. Emir-Öksüz, E.). İstanbul: Okuyan Us.

Yazıcıoğlu, Y. ve Erdoğan, S. (2004). Spss uygulamalı bilimsel araştırma yöntemleri. Ankara: Detay Yayıncılık.

Yıkılmaz, M. ve Demir-Güdül, M. (2015). Üniversite öğrencilerinde yaşamda anlam, bilinçli farkındalık, algılanan sosyoekonomik düzey ve yaşam doyumu arasındaki ilişkiler. Ege Eğitim Dergisi, 16(2): 297-315. 